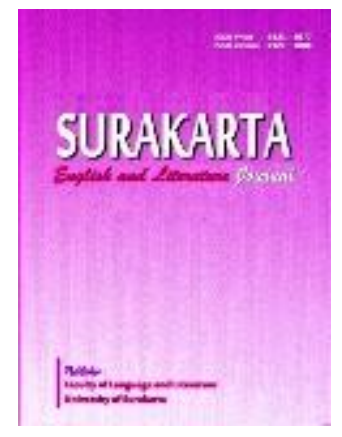

SURAKARTA ENGLISH AND LITERATURE JOURNAL

Vol 4 No 1 February 2021

Publisher Language and Literature Faculty, University of Surakarta

ISSN Print: 2621-9077 ISSN Online: 2621-9085

\title{
ERROR ANALYSIS ON THE STUDENTS' ENGLISH SPEECH OF STMIK SINAR NUSANTARA
}

\author{
Suryanti Galuh Pravitasari ${ }^{\mathrm{a}}$, Saly Kurnia Octaviani ${ }^{\mathrm{b},}$ Arumsari $^{\mathrm{b}}$ \\ anformation Technology, STMIK Sinar Nusantara Surakarta.bundagaluh@sinus.ac.id \\ 'Information System, STMIK Sinar Nusantara Surakarta. salyoctaviani@yahoo.com \\ 'Information System, STMIK Sinar Nusantara Surakarta. arumssari@gmail.com
}

\begin{abstract}
This research was aimed at finding out the student's English speech errors of STMIK Sinar Nusantara using psycho-linguistic approach. This study belongs to the qualitative descriptive research with 30 respondents selected by using simple random sampling. The data were collected by recording the students' presentation. After that the data were analyzed by conducting observation and classification the errors found in the respondents' speech using psycho-linguistic approach proposed by Clark and Clark. The result of the study showed that there were $336(100 \%)$ speech errors found which were than classified into Silent Pause (34\%), Filled Pause (13.7\%), Repeats (9.2\%), Retraced False Start 0.3\%), Corrections (4.5\%), Interjections (3.7\%), Stutters (14\%), dan Slip of Tongue (20.1\%).
\end{abstract}

Keywords: speech error, error analysis, qualitative-descriptive research

\section{INTRODUCTION}

As social creature, human being need language to continue their life. Without language, human will find difficulties communicating what they want. In addition, they will find difficulties in understanding messages given by the others. This is in line with what Fauziati (Fauziati, 2009) stated that, "Language is very critical to human lives and its main function is for communication". By it, human can interact with each other and communicate what they want. Therefore, they can gain the goal they have established.

During the communication, the message transferred by the other people is included in part of speech production in psycholinguistics. Speech production is related with, "why and how people say what they say" (Kess in Fauziati, 2009, p. 5). It gives more detailed explanation tha language functions as a media to transfer messages from one person to the others. It also supports that language also functions as a media to interact with the others. In this case, interaction with other people covers three crucial elements namely speaker, listener, and sound (Clark in Fauziati (2009, p. 9). 
The speaker must be able to send message using correct language to avoid misunderstanding. Therefore, speaking process involves two aspects, planning and speech execution. In planning speech, the speaker plans everything he will say to the audience. Meanwhile, in executing speech, the speaker says what he has planned in speech planning period.

However, although every time a speaker wants to deliver speech has carried out the two speech phases, errors may still take place especially when he is using foreign languages. It is true since natural speech is far from perfect. Speech errors are neutral phenomenon in which it might happen to anyone during delivering messages due to several causes. Meanwhile, filled and unfilled hesitation and errors may take place during normal speech. Therefore, speech error can be said as a mismatch between what the speaker want to deliver and what he actually says (Harley, 2006, p. 4). In addition, Wahyudi (2012, p. 30) also stated that speakers may make errors during his speech without notifying them. He usually cannot revise it as soon as possible especially when he is using foreign language. Speech errors can be in the form of pauses, repetitions, corrections, or improper diction. The speech errors of course result in improper message delivery.

Farida Indri Wijayanti (2012) mentioned that there are three sources of errors that might take place during a speech delivery proposed by Clark and Eve (1977). The first source is the cognitive reason. In this phase, people have difficulty in producing sentences using abstract words rather than the concrete ones. In addition hesitation may also appear at this period since people find it hard to get the correct words to express their idea. The second source of speech error is the situational anxiety in which people get anxious, tense, or worries about a certain situation. This might trouble them in delivering the speech as what they have planned before. The third reason why people make errors during their speech is the social factor. Speech seems becomes difficult when people deliver it in a situation which is under pressure. This tends to make hesitation occurs. When it happens, people usually take longer time to produce words. This may get the audience take over the speech.

This notion was also in line with what Brown states in Sholihah and Annisa (2019) stated that error was a faulty performance which might occur either in speech or written text indicating improper or incorrect system of learning. These errors did not indicate that the speaker intentionally commit it since he or she did not realize it. It was just an intention error (normal phenomenon) that a person might made during the message delivery due to the incomplete learning process.

There were two basic reasons of choosing the fifth semester students as the respondents of this research. The first reason was that they had already passed the previous four English subjects so that they were considered to have sufficient English speaking skill. The second one was that the subject of English V they were taking while in semester V was mostly about English for Public Speaking. In this subject, they also had to carry out a kind of mini research in which its result was to be the material to be presented, recorded and used as the research data

Based on the above description, the writer would like to find out the speech errors made by the respondents and the reasons why the errors take place. Th chosen of the fifth semester students as the respondents for this research is Therefore it is hoped that the speaking class would be modified as much as possible to eliminate the speech error sources. Hence the goal of the English speaking class will be met..

\section{METHODOLOGY}

This research belongs to qualitative research. Qualitative research is a research method which relies on positive philosophy. It is used to study a certain phenomena naturally. Naturally here means that the research is carried out naturally without manipulating the condition and emphasizing on the natural description (Sugiyono, 2008). This study also belongs to qualitative - 
descriptive research in which it deals with why and how a phenomenon has happened (Harley, 2006). This is in line with what Nawawi (1993) mentioned about qualitative research. According to him, a qualitative descriptive research is a research which efforts to reveal a phenomena, an event, or a condition as what is. In short, he said that qualitative research is merely a "fact finding". The data was collected qualitatively which was then analyzed quantitatively by using frequencies, percentages, averages, or other statistical analysis as proposed by Nassaji (2015). The data was collected by using the documentation method proposed by Marshal and Rossman (2006) by simply recording the students' speech. Once the data was collected, the researcher noted the errors he heard, classified the data in the distribution table and calculated them based on their frequencies, percentages and averages. The analysis was then carried out using the algorithm of conducting error analysis proposed by Corder (1978) which covers 3 basic phases namely recognition, description, and explanation. (Corder in Fauziati, 2009, p. 136)

The object of the research was the $5^{\text {th }}$ semester students of STMIK Sinar Nusantara, especially those who were taking English V class. The respondents were selected as many as 30 students by using purposive random sampling in which the respondents were selected based on certain criteria proposed by the researcher namely (1) the respondents were taking English V, (2). The respondents had to have passed English 1-4 since there were some transferred students who hadn't took the previous 4 English subjects, and (3) the respondents had to have completely carried out all process of the mini research. There were 6 classes with 150 students in total and taken randomly as many as $20 \%$ (30 students) to be the respondens. This technique of sampling was used since the researchers were eager to find out certain phenomenon (in here, the respondents' speech errors) as what Lawrence et.al (2015) stated in his manuscript entitled "Purposeful Sampling for Qualitative Data Collection and Analysis in Mixed Method Implementation Research". Meanwhile the method of the research was carried out in three steps as done by Permatasari et al. (2018) namely:

\section{Preparation :}

In this first step, the researchers read books, journals and other literature related to the topic of the research. The researchers explained the respondents about what they have to do during the data collection such as distributing the topics for their presentation, the length of their presentation and the recording process. The topic for the presentation was about a mini research findings. In this mini research, the respondents were asked to measure the satisfaction level of a certain institution by using simple questionaire distributed to the institution's service users. After that the result of the data was calculated, averaged, and interpreted. Finally, the respondents made a table about their findings for the presentation.

\section{Data Collection}

On the D day of the data collection, the respondents were asked to present their mini research findings one by one while the researcher recorded the presentations. The media used to do the recording was a smart phone. The number of the respondents were 30 people, therefore there were 30 MP3 files with around 5 minute length each.

\section{Data Analysis}

The data collected was then analyzed by using Speech Error Theory proposed by Clark and Clark (1977) in which he mentioned that there are nine types of speech error, namely Silent Pause, Filled Pause, Repeats, False Start (Unretraced), False Start (Retraced), Corrections, Interjections, Stutters, and Slip of Tongue. The researchers played the videos and observed them one by one carefully. The findings were classified in a table based on the nine types of speech error. 
The researchers then calculated the speech error findings based on their frequencies, distribution and averages. Finally the final findings of the research was interpreted by referring to some theories related with the study and compared them with some previous related studies.

\section{RESULTS AND DISCUSSION}

\section{Result}

Based on the research conducted by the researcher, the data collected from the 30 respondents can be seen in the following table of speech error distribution as proposed by Clark and Clark (1977).

Table 1. Speech Error Dsitribution

\begin{tabular}{|l|l|r|r|}
\hline NO & \multicolumn{1}{|c|}{ Types of Error } & \multicolumn{1}{|c|}{$\boldsymbol{\Sigma}$} & \multicolumn{1}{c|}{$\%$} \\
\hline 1 & Silent Pause & 116 & $34 \%$ \\
2 & Filled Pause & 46 & $13.7 \%$ \\
3 & Repeats & 31 & $9.2 \%$ \\
4 & False Start (Unretraced) & 0 & $0 \%$ \\
5 & False Start (Retraced) & 1 & $0.3 \%$ \\
6 & Corrections & 15 & $4.5 \%$ \\
7 & Interjections & 11 & $3.7 \%$ \\
8 & Stutters & 47 & $14 \%$ \\
9 & Slip of Tongue & 68 & $20.1 \%$ \\
\hline
\end{tabular}

Table 1 shows nine speech error classifications made by the 30 respondents. There are 336 speech errors in total with the biggest one is the Silent Pause which contributed as many as 116 errors or $34 \%$ to the whole. This is in line with what Fauziati (2009: 76) stated that the error most frequently made by the foreign language speaker was the Silent Pause. It was a period in which there was no voice at all produced by the speaker.

Here are some Silent Pauses that could be recorded by the writer:

1. I will present mini research // about customer's satisfaction toward...

2. Good evening guys // I will present ...

3. And see // overall performance ...

4. I will tell you about first aspect is // personal // in the aspect of personal.

5. We still got // a lot of lot hole.

6. The // one respondent saying very good of hospitality.

7. This new research // aimed at measuring // the level of customer service satisfaction.

8. We can be that responding // that STMIK Sinar Nusantara on the performance Pascal.

9. In here, I will // present // about laboratory II in STMIK Sinar Nusantara.

10. I'm in here in to present // survey about library.

From Table 1, we can also see that the second biggest speech error is the Slip of Tongue which appeared 68 times during the presentation conducted by the 30 respondents. It means, Slip of Tongue contributes $20.1 \%$ to the whole speech errors. Slip of Tongue is unintended, non habitual deviation (s) from a speech plan. (Dell in Poulisse in Fauziati, 2009 : 78). Moreover, Fauziati stated that Slip of Tongue is a type of speech errors which is more complex that the other ones. People slip their tongue now and again, most often when tongue's owners are tired, a bit drunk, and or rather nervous.(2009:78).

Here are some Slips of Tongue that could be recorded by the writer:

1. There are contain (contant).

2. Respondents said fight (fair) 
3. I'm going to presentate about customer statisfication (satisfication).

4. And then, aspect number four, security necessity (CCTV).

5. In there I will explain to my research and my resus about satisfication.

6. The point is thirty (thirteen).

7. Hopefuliffy, it cold be the best.

8. This overall performance is collor purfple.

9. Less smoke in the lab, hit (head) lab too strict...

10. The riset (research) was about ...

The third biggest speech error as shown in Table 1 is Stutters which appeared 47 times or contributed $14 \%$ to the total speech errors found in the video. Stutters is a period in which a speaker repeats the same sound or syllable for several times, for example "Turn on the $\mathrm{h}-\mathrm{h}$ - $\mathrm{h}$ heater switch". (Fauziati, 2009:77).

Several samples of stutters that have been found by the researcher are as follows:

1. it is a- a- done ...

2. About a-a customer satisfaction.

3. It is too- too high.

4. This is a- a feedback.

5. I will a- a present ....

6. My observation about customer s- s- satisfaction.

7. And th- th- th- the normal collegian in STMIK can be said...

8. However, uh, some s- s- suggestions, are shared by respondents.

9. As- as- aspects- aspect, fasilitas, bunker ...

10. Less smoke in the lab, hit lab too strict in the ru-u-les of the lab

Next, the fourth biggest speech error found in the videos as shown on Table 1 is Filled Pause. It appeared 46 times or contributed $13.7 \%$ to the total number of speech error. Filled Pause is a gap filled ah, er, uh, $\mathrm{mm}$ such as in Turn on, mm, the heater witch. (Fauziati, 2009:76).

Here are some Filled Pauses that could be found in this research :

1. Uh../ This is, uh, my job observation.

2. Uh.../ I'm going to presentate about customer statisfoication.

3. Aspect number two, uh../ first, the size of parking area, parkir availability, and comfort.

4. Uh../ in there I will explain to my research and my resus about satisfication.

5. Umm.., who the $20 \%$ mean very very less started.

6. I did uh..uh..questionnaire....

7. And then uh..uh my research ....

8. And the uh-uh first ....

9. And then is uh..uh good ...

10. This is uh..uh diagram

The fifth frequently appeared speech errors made by the 30 respondents in this study was the Repeats. It appeared 31 times. Therefore it contributed $9.2 \%$ to the whole speech errors. A speaker produces this error when he repeats one or more words in a row such as Turn on the heater/the heater switch. (Fauziati, 2009:76).

The samples of the Repeats made by the respondents in this study are listed below:

1. In the diagram / diagram ...

2. You can see / see ...

3. We look at the diagram / diagram ...

4. Number one / one is...

5. In the table / table ...

6. I think enough / I think enough

Surakarta English and Literature Journal 
7. respondent saying very good, uh, in the / in the response, fast response

8. As aspects / aspect, fasilitas, bunker ...

9. And this suggestion from / from 25 university students

10. Out of 25 respondents, 23 were/ 23 were saying that ...

The sixth biggest error made by the respondents during their presentation in their videos as shown on Table 1 is Correction. It appeared 31 times. Therefore it contributed $9.2 \%$ to the whole speech errors found in this study.

Here are some Corrections that could be found by the writer in this study:

1. The information just from.../ just for the member club

2. I am, uh, will/ I will to explain

3. And then, aspect number four, security necessity/ CCTV availability

4. This is from/ for diagram satisfication

5. And the overall, overall performance is / 13 saying that the overall performance of the lab 2 is bad

6. who stated say of rarely service / clean place

7. I am, uh, will/ I will to explain

8. respondent saying very good, uh, in the / in the response /the fast response.

9. And the overall, overall performance is/ 13 saying that the overall performance of the lab 2 is bad 10. $20 \%$ statis less 7 and ex perce-/ per people

The seventh biggest speech error found in this study was Interjection. As Tables 1 shows, the respondents made 11 interjections during their presentation in English as their foreign language. Hence, interjection contributed $3.7 \%$ to the speech errors found in this study in a whole. Like hesitation pause, Interjection indicate that the speakers have had to stop to think about what to say next. The interjection in English often emerges with the sounds oh, ah, well, and say such as in John would like, oh, carrots'. (Fauziati, 2009: 77).

Some interjections that could be recorded by the writer in this study as as follows:

1. And oh wifi ...

2. It has been oh..oh started..

3. And then oh..oh professional

4. I will present about.. oh... the customer satisfaction on ...

5. There are about three.. oh ... thirty people saying ...

6. The diagram shows that the first oh.. category is ..

7. The oh next diagram says ...

8. Finally, I can conclude that the ... oh... service of ...

9. The number of people saying that .. oh the service ...

10. It can be .. oh. Concluded that ...

The $8^{\text {th }}$ type of error speech appearing in the respondents' video as seen on Table 1 is the Retraced False Start. A retraced false start is an error in the form of repeating one or more word before the correct one is produced. (Fauziati, 2009:77). In all the 30 videos used as the data of this study, there was only one Retraced False Start found. Therefore it only contributes $0.3 \%$ to the total number of the speech error. The only sentence containing the Retraced False Start is 'The height / the accurate number is 35\%'.

Finally, the only type of error speech proposed by Clark and Clark in Fauziati, $2009: 77$ is the unretraced false start.

\section{DISCUSSION}

The findings as illustrated above agreed with what was stated by Goldman-Eisler in by Fauziati (2009: 75) that most speakers make much pausing as much as 40 - 50\% during their 
speech. It was proven by the findings that the respondents made pausing as much as 162 times. It means, they made $48.2 \%$ speech error of pausing of the $100 \%$ error speech. The pausing itself was divided into two categories namely Silent Pausing (116 times or 34.5\%) and Filled Pausing (46 times or $13.6 \%$ ).

This finding is in line with what Saputri (2016, p. 185) found in her study that among 232 error speeches, the $91 \%$ of them was in the form of Silent Pause $(10.73 \%)$ and Filled Pause (80.28\%). Kafifah and Aini (2020) also found the same findings in their research that the Silent Pause contributed most to the total number of errors made by the respondents. The finding on the number of error speech in the form of Silent Pause and Filled Pause is also the same as what Utami and Malihah (2018, p. 1991) found in her study that among 603 pausing speech errors, the Silent Pause appeared 524 times or contributed to the whole error speech number while the rest was Filled Paused which appeared 79 times or $13 \%$ of the total. Another study conducted by Firdausi (2016) showed that the most error found was also the Silent Pause in which it contributed as many as $44.27 \%$ to the total number of errors.

However, the comparison on the number of speech error between Silent Pause and the Filled Pause in this research is different from those in Saputri (2016, p. 185) and Muthmainnah (2014). In her study, Rismanita found that Filled Pause appeared more commonly $(80.28 \%)$ than the Silent Pause (10.73\%). Muthmainnah (2014) also found out that errors on the Filled Pause contributed more errors (35.4\%) than Silent Pause (23.9\%). In contrast, errors in Silent Pause (34\%) found in this research was bigger than the Filled Pause (13.7\%).

There are two major causes or sources of the speech errors found in this study as stated by Clark and Clark in Fauziati (2009, p. 74), namely first, the errors appeared as a result of the respondents' difficulty in planning and executing the idea at the same time. Hesitations, corrections, and pauses, for examples, are typical speech errors which are resulted from such difficulties. It is proven by the finding in this research that $52 \%$ of the total speech errors belong to Silent Pause (34\%), Filled Pause (13.7\%), and Correction (4.5\%).

The second source of speech error is the result of the difficulty the respondents have to deal with in executing articulation program to guide the articulation muscles in producing sound. The result is in the forms of Slip of Tongue which usually takes place when the speaker are tired, in a hurry, or under pressure. This is also what the writer found in this study that the Slip of Tongue was $20,1 \%$, Stutters (14\%), Interjections $(3.7 \%)$, corrections (4.5\%), and repeats $(9.2 \%)$. See Table 1.

Therefore, the implication of the result and the discussion of this research is that it is crucial to give more portions on speaking activities during English classes. It is also important to consider that there should be additional programs that support the achievement of the speaking class goal outside the class. The more frequent the opportunities given to the students to use their English orally, especially in front of public, the higher their English speaking skill will be. Hence, the speech errors made by them will also decrease.

\section{CONCLUSION(S)}

There are several things to be concluded from the research findings:

1. Among the nine types of error speech proposed by Clark and Clark in Fauziati $(2009$, p. 77), there are only eight types found in this research, namely Silent Pause, Filled Pause, Retraced False Start, Corrections, Interjections, Stutters, and Slip of Tongue.

2. The most frequent speech error found in this research is the Silent Pause (116 or 34\%) The second is Slip of Tongue which appeared 68 times (20,1\%), then Filled Pause of 46 times $(13,7 \%)$, next Repeats which appeared as many as 31 times $(9.2 \%)$. After that is Corrections

\section{Surakarta English and Literature Journal}


which came up as many as 15 times (4.5\%), then interjections which appeared 11 times (3.7\%), and finally the last one is the Retraced False Start which only appeared once $(0.3 \%$ of the whole 366 speech errors).

3. The only speech error which was not found by the researcher was Unretraced False Start.

This research found out that there were also two main sources of the speech errors, namely the respondents' difficulty in planning and executing ideas at the same time and that the they also found difficulty in forming the articulatory program to guide the articulatory muscles in executing sounds.

Finally, there are still many other aspects that can be done to generate researches on speech errors such as analyzing the effectiveness of certain instrument or teaching techniques used in class to decrease the error that have been found out. Moreover, there should also be a research on studying the materials and the syllabus given in the class to know whether they also contribute the errors made by the students while using their English.

\section{REFERENCES}

Clark, H. H., \& Eve., V. (1977). Psychology and Language: An Introduction to Psycholinguistics. Harcourt Brace Javanovich, Inc.

Fauziati, E. (2009a). Psycholinguistics: An Introduction. Era Pustaka.

Fauziati, E. (2009b). Readings on Applied Linguistics: A Handbook for Language Teacher and Teacher Researcher. Era Pustaka.

Firdausi, A. P. (2016). Error Analysis in Oral Production Made by Students of Civil Engineering: A Case Study in English Tutorial Program (ETP) at Universitas Muhammadiyah Surakarta. JoLLIET, $3(1), \quad 12-26$. http://journals.ums.ac.id/index.php/JoLLIET/article/download/2116/1507

Harley, T. (2006). Speech Error: Psycholinguistics Approach. In Encyclopedia of Language and Linguistics.

Muthmainnah. (2014). The Analysis of Speech Errors Made by the Main Actors in "Bad Boys I: The Movie" at Education Faculty of Al Asy Ariah Mandar University 2014. In Jurnal Pepatuzdu (Vol. 8, Issue 1). https://doi.org/10.35329/FKIP.V8I1.22

Nassaji, H. (2015). Qualitative and descriptive research: Data type versus data analysis. Language Teaching Research, 19(2), 129-132. https://doi.org/10.1177/1362168815572747

Nawawi, H. (1993). Metode Penelitian Bidang Sosial. Gadjah Mada University Press.

Palinkas, L. A., Horwitz, S. M., Green, C. A., Wisdom, J. P., Duan, N., \& Hoagwood, K. (2015). Purposeful Sampling for Qualitative Data Collection and Analysis in Mixed Method Implementation Research. Administration and Policy in Mental Health and Mental Health Services Research, 42(5), 533-544. https://doi.org/10.1007/s10488-013-0528-y

Permatasari, A. D., Wijayatiningsih, T. D., \& Mulyadi, D. (2018). Error Analysis on EFL Learners' Analytical Exposition Writing. Surakarta English and Literature Journal, 1(1), 22-30. https://doi.org/10.29240/SELJU.V1I1.204

Saputri, R. A. E. (2016). Errors on Oral Production Made by English Department Students in Microteaching Class at Universitas Muhammadiyah Surakarta. Jurnal Penelitian Humaniora, 17(2), 185. https://doi.org/10.23917/humaniora.v17i2.2510 
Sholihah, U., \& Anisa, I. (2019). ERROR ANALYSIS ON DESCRIPTIVE TEXT OF NONENGLISH TEACHERS AT AL ISLAM JUNIOR HIGH SCHOOL KARTASURA. In Surakarta English and Literature Journal (Vol. 2, Issue 2). https://doi.org/10.29240/SELJU.V2I2.272

Sugiyono. (2008). Penelitian Kuantitatif, Kualitatif dan $R \& D$. Alfabeta.

Utami, A. R., \& Malihah, N. (2018). Speech Errors Produced by EFL Learners of Islamic Boarding School in Telling English Story. OKARA: Jurnal Bahasa Dan Sastra, 12(2), 191. https://doi.org/10.19105/ojbs.v12i2.1930

Wahyudi, E. (2012). Grammatical Error Analysis in Students' Reported Speech (The Case of the Eleventh Grade Students of SMA Negeri Gondangrejo Karanganyar in 2010/2011 Academic Year). https://digilib.uns.ac.id/dokumen/27014/Grammatical-Error-Analysis-in-StudentsReported-Speech-The-Case-of-the-Eleventh-Grade-Students-of-SMA-Negeri-GondangrejoKaranganyar-in-20102011-Academic-Year

Wijayanti, F. (2012). Speech Errors in a Talk Show Program of Metro TV "Face to Face with Desi Anwar" Broadcasted in January to June 2012. Jurnal Penelitian Humaniora, 13(2), 108-119. http://journals.ums.ac.id/index.php/humaniora/article/view/889 